\title{
Heterotic Effect, Combining Ability and Significance of Synthetics over Line Cultivars in Faba Bean (Vicia faba L.) Grown under Semi-Arid Zones
}

\author{
Seif M. Gasim¹ ${ }^{*}$, Alam E. Mohamed² \\ ${ }^{1}$ Department of Agronomy, Faculty of Agriculture, University of Khartoum, Shambat, Sudan \\ ${ }^{2}$ Department of Agronomy, Faculty of Agriculture, University of Zalingei, Zalingei, Sudan \\ Email: *seifm1963@gmail.com
}

How to cite this paper: Gasim, S.M. and Mohamed, A.E. (2018) Heterotic Effect, Combining Ability and Significance of Synthetics over Line Cultivars in Faba Bean (Vicia faba L.) Grown under Semi-Arid Zones. American Journal of Plant Sciences, 9, 2684-2695.

https://doi.org/10.4236/ajps.2018.913195

Received: November 22, 2018

Accepted: December 18, 2018

Published: December 21, 2018

Copyright $\odot 2018$ by authors and Scientific Research Publishing Inc. This work is licensed under the Creative Commons Attribution International License (CC BY 4.0).

http://creativecommons.org/licenses/by/4.0/

\begin{abstract}
The aim of this study was to investigate the amount of heterosis and performance of faba bean synthetic cultivars compared to line cultivars under semi-arid conditions. Five inbred lines in at least $\mathrm{S}_{6}$ generation were developed and used to develop $F_{1}$ s hybrid (in all possible combination excluding reciprocal), lines mixtures (Syn-0) and synthetic generations of Syn-1. Evaluation of the entries showed the lines to have high general and specific combining ability, high yield and high average degree of cross-fertilization (0.36); hetrosis relative to mid-parent for yield was $67 \%$. Lines mixture from four inbred lines (Hudeiba/93, Bassabier, Ed-Damar and Shabah) gave the highest yield of $3.40 \mathrm{t} / \mathrm{ha}$ for Syn-0 and $3.96 \mathrm{t} / \mathrm{ha}$ for Syn-1. Compared to the average yield $t / h a$ of the pure stand of the four lines $(3.11 \mathrm{t} / \mathrm{ha})$, the increase in yield of was $9 \%$ in sy-0 and 27\% in Syn-1. Compared to the individual yield $t / h a$ of the pure stand of the lines, the performance of Syn-0 surpassed that of the individual pure stands of the linesby $14 \%$ for Hudiaba/93 and Bassabier and $4 \%$ for Ed-Damar and 7\% for Shabah, whereas the increase in performance of Syn- 1 compared to pure stand of the lines was $32 \%, 25 \%$ and $21 \%$, respectively. The results confirm the previous knowledge on yield increase with successive syn-generations in faba bean due to the effects of heterogeneity and heterozygosity. Such results could be used as a base for an effective breeding program for improvement of yield of faba bean grown under the semi-arid zones.
\end{abstract}

\section{Keywords}

Hetrosis, Synthetics, Faba Bean, Yield, Arid-Zone 


\section{Introduction}

Faba bean is the most important food legume crop in North (Morocco, Egypt and Sudan) and East (Ethiopia) Africa. It contributes to the main human nutrition, supplying high quality protein crucial for a balance diet of millions of people who cannot afford meat as a source of protein. In addition, faba bean has been shown to increase soil fertility through biological $\mathrm{N}_{2}$-fixation that can be used by the succeeding cereal crops and to break the cycle of biotic stresses [1]. The crop is grown under irrigated condition in Egypt and Sudan and under rain-fed in Morocco and Ethiopia. However, in Sudan (semi-arid zone), despite their importance as highly nutritious food stuffs, the productivity of crop is instable and far below its potential. Climate change, where the weather is becoming hotter and the season is shorter at the traditional production areas in the north, is among the most important constrains of the low productivity in Sudan [2].

To produce stable and high yield in faba bean, synthetic cultivars were recommended [3] as the commercial production of hybrid cultivars is not yet feasible due to the insufficient stability of the existing male sterility system [4]. Such cultivars were found to use part of the heterosis present in faba bean plant $(75 \%$ as reported by [5] [6]) as well as their ability to adapt environmental variation, [3]. Although synthetic cultivars are less productive than heterotic hybrids, their main advantage is that the heterosis does not diminish significantly in $F_{2}$ [7]. Such variety is developed by selecting superior inbred lines having high combining ability and high heterosis [8] [9]. The objective of the present study was to assess the amount of heterosis in Sudanese faba bean as pre-requisite for production synthetic cultivars.

\section{Material and Methods}

\subsection{Genetic Material and Field Experiment}

Five inbred lines (in at least S6 generation) developed via single seed decent from the five locally grown faba bean cultivars in Sudan (Selaim, Hudeiba/93, Ed-Damar, Bassabier, and Shabah), representing a wide range of genetic variability in their agronomic traits (plant height, number of pods/plant, 100 seed weight, and yield), were used to fulfill the objectives of the present study. These lines were sown in isolated cages for multiplication (by hand tripping) and for cross purposes by hand in all possible combinations (in diallel cross excluding reciprocals) to produce $F_{1}$ seeds.

Three experiments were carried out at the Demonstration Farm of the Faculty of Agriculture, University of Khartoum, Shambat (latitude $15^{\circ} 40^{\prime} \mathrm{N}$; longitude $32^{\circ} 32^{\prime} \mathrm{E}$, and altitude 380 meter above sea level). The site is located in the semi-arid zone; the soil is alkaline ( $\mathrm{pH} 8.0$ ); rainfall is about $150 \mathrm{~mm}$ per annum and with maximum temperature of about $42^{\circ} \mathrm{C}$ in summer and around $21^{\circ} \mathrm{C}$ in winter [10].

In experiment I, the seeds of the lines (parents) and $F_{1}$ s were grown in seasons 
2014/2015-2015/2016 to test the lines for general (GCA) and specific (SCA) coming ability.

In experiment II, the lines were evaluated in seasons 2014/2015-2015/2016 for the degree of cross-fertilization as described by Link [11] using the black hilum color as morphological marker. On average, from each entry 192 progeny were screened by year.

In experiment III, an equal number of seeds ( 25 seeds) from each of the five inbred lines [Hudeiba/93 $\left(\mathrm{L}_{1}\right)$, Ed-Damar $\left(\mathrm{L}_{2}\right)$, Shabah $\left(\mathrm{L}_{3}\right)$, Bassabeir $\left(\mathrm{L}_{4}\right)$ and Selaim $\left(\mathrm{L}_{5}\right)$ ] were blended in all possible combination. Accordingly, sixteen blends/mixtures (M1 to M16) were developed. The line blends (one from all lines, five blends from four lines and ten blends from three lines) called Syn-0, were grown in season 2014/2015 under open pollination in spatial isolation to produce Syn-1seed. The seed of the lines blend (Syn-0) and that of Syn-1 were grown in season 2015/2016 and evaluated for yield and yield components.

Complete randomized block design with three replicates was used to execute the experiments. The gross plot size in the two experiments was $6.3 \mathrm{~m}^{2}$ consisting of 3 ridges each $3 \mathrm{~m}$ in length and $70 \mathrm{~cm}$ apart. One seed was planted per hole with the spacing of $10 \mathrm{~cm}$ along the ridge. The experimental plots were irrigated every 14 days and weeded three times using hand hoe. The experiment was carried out in the presence of pollinators; here honeybee (Apis mellifera sp.) was introduced in the field of the experimental area.

\subsection{Data Collection and Analysis}

Data were collected from the parameters of: 1) days to flowering, determined when $50 \%$ of the plants of each entry open the first flower, 2) Plant height measured in $\mathrm{cm}$ at the end of the flowering period, 3) Number of pods per plant, 4) 100-seed weight ( $\mathrm{g}$ ), and 5) seed yield $\mathrm{t} / \mathrm{ha}$. The data were subjected to analysis of variance (ANOVA) according to the method described for the randomized complete block design (RCBD). The computer program SAS-1997version 9.0 was used for the analysis of variance.

The heterotic effects of $F_{1}$ crosses were estimated as a percentage over mid parent [12] as follows:

Relative heterosis $(\mathrm{RH})(\%)=\frac{F_{1}-\text { Midparent }}{\text { Midparent }} \times 100$

Data for general combining ability (GCA) and specific combing ability (SCA) were analyzed as described by [13] for method 2 model I (all possible combination excluding reciprocal) as follows:

$$
Y_{i j}=\mu+G C A_{i}+G C A_{j}+S C A_{i j}+e_{i j k l}
$$

where:

$Y_{i j}=$ Observation of $i$ th parent in the th block;

$\mu=$ population mean;

$G C A_{i}=$ general combining ability (g.c.a) effect of the $i$ th parent;

$G C A_{j}=$ general combining ability (g.c.a) effect of the $j$ th parent; 
$S C A_{i j}=$ specific combined effect (s.c.a) of two parents;

$e_{i j k l}=$ experimental error.

The standard error required for testing the significance of general combining ability effects of the parents $(p)$ and differences of GCA effects were obtained as:

$$
\begin{gathered}
S . E_{\cdot \hat{g}_{i}}=\left(\frac{(P-1)}{p(p+2)} \sigma_{e}^{2}\right)^{1 / 2} \\
\text { and } S . E_{\cdot(\hat{g} \dot{i}-\hat{g})}=\left(\frac{2}{p+2} \sigma_{e}^{2}\right)^{1 / 2}
\end{gathered}
$$

Three errors required for testing the significance of specific combining ability effect of the parents $(p)$ and differences of SCA effects were estimated as:

$$
\begin{aligned}
& S . E_{\cdot s i j}=\left(\frac{P^{2}+P+2}{(p+1)(p+2)} \sigma_{e}^{2}\right)^{1 / 2} \\
& S . E_{\cdot(s i j-s i k)}=\left(\frac{2(P+1)}{(p+2)} \sigma_{e}^{2}\right)^{1 / 2} \\
& \text { and } S . E_{\cdot(s i j-s k l)}=\left(\frac{2 P}{p+2} \sigma_{e}^{2}\right)^{1 / 2}
\end{aligned}
$$

\section{Results}

\subsection{Variation and Mean Performance of the Entries}

Mean squares from the analysis of variance for the studied traits in the 15 entries (parental lines and their $F_{1} \mathrm{~s}$ ) revealed highly significant differences, except for number of days to $50 \%$ flowering which exhibited non-significant differences (data not shown). Comparing the crosses performance with their corresponding parental lines, none of the lines exceeded hybrid performance in any of the studied traits (Table 1). For the lines, plant height was in the range from $74.40 \mathrm{~cm}$ for Hudeiba/93 to $70.00 \mathrm{~cm}$ for Seliam with an average of $72.50 \mathrm{~cm}$. The performance of the $F_{1}$ s, plant height ranged from $88.70 \mathrm{~cm}$ (Hudeiba/93 $\times$ Shaba) to $76.00 \mathrm{~cm}$ (Bassabier $\times$ Selaim) with an average of $81.50 \mathrm{~cm}$. Number of pods per plant in the lines was in the range from 18.37 registered by Seliam to 27.00 in Bassabier and averaged to 23.20. In $F_{1}$ s, the cross of $\mathrm{L} 2 \times \mathrm{L} 4$ gave the highest number of pod per plant and cross L3 $\times$ L5 the lowest one. Although the line Shabah had the highest 100-seedweight $(71.40 \mathrm{~g})$ and yield $(3.17 \mathrm{t} / \mathrm{ha})$ compared the other lines, the cross of Ed-Damar $\times$ Bassabier gave the highest number of pods/plant and yield (5.60 t/ha).

\subsection{Combining Ability}

Mean squares from the analysis of variance for GCA and SCA for the studied traits are presented in Table 2. The results indicated that the effect of general combining ability (GCA) for parental lines and specific combining ability (SCA) 
for crosses among the lines were highly significant $(p \leq 0.01)$ for all of the studied traits; the GCA was greater than SCA. Among the lines, Bassabier exhibited the highest positive GCA for number of pods per plant (1.29) and yield t/ha (0.08) (Table 3). Line Hudeiba/93 gave the highest positive GCA of 0.94 for plant height; Shabah line exhibited the highest (0.51) positive GCA for 100-seed weight, but the highest $(-1.64)$ negative GCA for number of pods per plant. On the other hand, Selaim exhibited the highest $(-0.19)$ negative GCA for yield $t / h a$.

For SCA, the magnitude of the crosses varied for the different traits e.g. the cross of Ed-Damar $\times$ Bassabier $\left(\mathrm{L}_{2} \times \mathrm{L}_{4}\right)$ showed the largest $(33.52 \mathrm{~cm})$ positive SCA effect for plant height and number of pods per plant (26.42); the cross of Shabah $\times$ Selaim $\left(\mathrm{L}_{3} \times \mathrm{L}_{5}\right)$ exhibited the largest (26.02) positive SCA effect for 100-seed weight (Table 4). Moreover, Hudeiba $\times$ Ed-Damar $\left(\mathrm{L}_{1} \times \mathrm{L}_{2}\right)$, Ed-Damar $\times$ Shabah $\left(\mathrm{L}_{2} \times \mathrm{L}_{3}\right)$ and Shabah $\times$ Bassabier $\left(\mathrm{L}_{3} \times \mathrm{L}_{4}\right)$ showed the highest (2.00) positive SCA effect for yield $t / h a$.

Table 1. Mean performance of yield and yield traits in fifteen faba bean entries.

\begin{tabular}{|c|c|c|c|c|c|}
\hline Entry/trait & $\begin{array}{c}\text { Days to } \\
\text { flowering }\end{array}$ & $\begin{array}{c}\text { Plant } \\
\text { height }(\mathrm{cm})\end{array}$ & Pods/plant & $\begin{array}{c}\text { 100-seed } \\
\text { weight (g) }\end{array}$ & $\begin{array}{l}\text { yield } \\
\text { (t/ha) }\end{array}$ \\
\hline Hudeiba/93 (L1) & 45.30 & 74.40 & 25.13 & 55.80 & 2.99 \\
\hline Ed-Damar (L2) & 45.00 & 72.50 & 24.90 & 57.63 & 3.17 \\
\hline Shabah (L3) & 45.00 & 73.00 & 20.60 & 71.40 & 3.27 \\
\hline Bassabeir (L4) & 45.30 & 72.60 & 27.00 & 55.43 & 2.99 \\
\hline Selaim (L5) & 44.30 & 70.00 & 18.37 & 67.30 & 2.96 \\
\hline Mean & 44.98 & 72.50 & 23.20 & 61.51 & 3.07 \\
\hline $\mathrm{L} 1 \times \mathrm{L} 2\left(F_{1}-1\right)$ & 45.30 & 84.73 & 42.00 & 68.77 & 5.10 \\
\hline $\mathrm{L} 1 \times \mathrm{L} 3\left(F_{1}-2\right.$ & 44.70 & 88.70 & 37.00 & 68.90 & 5.20 \\
\hline $\mathrm{L} 1 \times \mathrm{L} 4\left(F_{1}-3\right)$ & 45.00 & 85.16 & 39.00 & 68.50 & 5.11 \\
\hline $\mathrm{L} 1 \times \mathrm{L} 5\left(F_{1}-4\right)$ & 45.70 & 79.23 & 35.00 & 69.30 & 4.90 \\
\hline $\mathrm{L} 2 \times \mathrm{L} 3\left(F_{1}-5\right)$ & 45.30 & 80.00 & 37.00 & 71.97 & 5.20 \\
\hline $\mathrm{L} 2 \times \mathrm{L} 4\left(F_{1}-6\right)$ & 46.00 & 83.20 & 49.00 & 69.13 & 5.60 \\
\hline $\mathrm{L} 2 \times \mathrm{L} 5\left(F_{1}-7\right)$ & 45.70 & 81.40 & 36.00 & 70.37 & 5.00 \\
\hline $\mathrm{L} 3 \times \mathrm{L} 4\left(F_{1}-8\right)$ & 45.70 & 77.80 & 37.00 & 69.00 & 5.23 \\
\hline $\mathrm{L} 3 \times \mathrm{L} 5\left(F_{1}-9\right)$ & 45.30 & 78.30 & 33.00 & 73.60 & 5.25 \\
\hline $\mathrm{L} 4 \times \mathrm{L} 5\left(F_{1}-10\right)$ & 45.30 & 76.00 & 35.00 & 70.80 & 4.70 \\
\hline Mean & 45.40 & 81.50 & 38.00 & 70.03 & 5.14 \\
\hline Gran mean & 45.25 & 76.62 & 31.6 & 66.90 & 4.10 \\
\hline C.V & 3.02 & 4.13 & 3.09 & 1.94 & 8.01 \\
\hline $\mathrm{LSD}_{0.05}$ & - & 2.61 & 0.94 & 1.24 & 0.34 \\
\hline
\end{tabular}


Table 2. Mean squares from the analysis of variance for general (GCA), specific (SCA) combining ability and error for yield and yield components in faba bean genotypes.

\begin{tabular}{cccccc}
\hline $\begin{array}{c}\text { Source of } \\
\text { variation }\end{array}$ & $\begin{array}{c}\text { Degree } \\
\text { of freedom }\end{array}$ & $\begin{array}{c}\text { Plant } \\
\text { height }(\mathrm{cm})\end{array}$ & Pods/plant & $\begin{array}{c}\text { 100-seed } \\
\text { weight }(\mathrm{g})\end{array}$ & Yield (t/ha) \\
\hline GCA & 4 & $4820.83^{* *}$ & $1034.87^{\star *}$ & $3501.66^{* *}$ & $21.61^{\star *}$ \\
SCA & 10 & $338.88^{\star *}$ & $112.99^{* *}$ & $235.90^{\star *}$ & $1.61^{\star *}$ \\
Error & 18 & 5.719 & 0.495 & 0.261 & 0.098 \\
\hline
\end{tabular}

${ }^{* *}=$ significant difference at 0.01 .

Table 3. Estimation of general combining ability effect of five faba bean inbred lines for yield and yield components.

\begin{tabular}{ccccc}
\hline Line/trait & Plant height $(\mathrm{cm})$ & Pods/plant & 100-seed weight $(\mathrm{g})$ & Yield t/ha \\
\hline Hudeiba/93 (L1) & 0.94 & 0.77 & -0.41 & 0.02 \\
Ed-Damar (L2) & 0.29 & 0.52 & 0.14 & 0.05 \\
Shabah (L3) & -0.28 & -1.64 & 0.51 & 0.05 \\
Bassabeir (L4) & 0.12 & 1.29 & -0.62 & 0.08 \\
Selaim (L5) & -0.06 & -0.94 & 0.39 & -0.19 \\
S. $E_{\cdot \hat{g}_{i}}$ & 0.81 & 0.36 & 0.17 & 0.11 \\
S.E. $E_{(\dot{g} \dot{i}-\hat{g})}$ & 1.28 & 0.57 & 0.27 & 0.17 \\
\hline
\end{tabular}

** = significant difference at 0.01 .

Table 4. Estimation of specific combining ability effect of $F_{1}$-hybrids for yield and yield components in faba bean.

\begin{tabular}{|c|c|c|c|c|}
\hline Cross/trait & Plant height $(\mathrm{cm})$ & Pods/plant & 100 -seed weight $(\mathrm{g})$ & Yield $\mathrm{t} / \mathrm{ha}$ \\
\hline $\mathrm{L} 1 \times \mathrm{L} 2$ & 32.17 & 13.66 & 22.73 & 2.04 \\
\hline $\mathrm{L} 1 \times \mathrm{L} 3$ & 28.58 & 12.96 & 23.59 & 1.87 \\
\hline $\mathrm{L} 1 \times \mathrm{L} 4$ & 22.46 & 6.89 & 23.26 & 1.87 \\
\hline $\mathrm{L} 1 \times \mathrm{L} 5$ & 30.08 & 20.32 & 22.11 & 1.64 \\
\hline $\mathrm{L} 2 \times \mathrm{L} 3$ & 22.20 & 7.18 & 23.31 & 2.12 \\
\hline $\mathrm{L} 2 \times \mathrm{L} 4$ & 33.52 & 26.42 & 23.11 & 1.72 \\
\hline $\mathrm{L} 2 \times \mathrm{L} 5$ & 22.81 & 5.55 & 24.76 & 1.65 \\
\hline $\mathrm{L} 3 \times \mathrm{L} 4$ & 25.63 & 12.77 & 22.44 & 2.13 \\
\hline $\mathrm{L} 3 \times \mathrm{L} 5$ & 27.98 & 11.27 & 26.02 & 1.40 \\
\hline $\mathrm{L} 4 \times \mathrm{L} 5$ & 28.41 & 9.84 & 22.05 & 1.90 \\
\hline S.E. $E_{s i j}$ & 14.6 & 0.49 & 3.10 & 1.91 \\
\hline S.E. $E_{(s i j-s i k)}$ & 2.39 & 0.7 & 0.51 & 0.31 \\
\hline$S . E_{\left.{ }_{(\hat{s} i j-} \hat{s i k}\right)}$ & 1.95 & 0.57 & 0.41 & 0.26 \\
\hline
\end{tabular}

** $=$ significant difference at 0.01 . 


\subsection{Effects of Heterosis}

Values of heterosis percentage relative to mid parents for the studied traits are presented in Table 5. The mean values were ranged from 10.50 for 100 -seed weight to $67 \%$ for yield $\mathrm{t} / \mathrm{ha}$. Heterosis in plant height was in the range from $6 \%$ to $21.2 \%$ with an average of $12 \%$. The highest plant height heterosis of $21.2 \%$ was given by the cross $\mathrm{L}_{1} \times \mathrm{L}_{3}$ followed by the crosses of $\mathrm{L}_{1} \times \mathrm{L}_{2}(17 \%), \mathrm{L} 1 \times \mathrm{L}_{4}$ (16.15\%) and $\mathrm{L}_{2} \times \mathrm{L}_{4}(15 \%)$. Number of pods per plant exhibited heterosis values ranged from $50 \%\left(\mathrm{~L}_{1} \times \mathrm{L}_{4}\right)$ to $89 \%\left(\mathrm{~L}_{2} \times \mathrm{L}_{4}\right)$ with an average of $64 \%$. Six crosses $\left(\mathrm{L}_{1} \times \mathrm{L}_{2}, \mathrm{~L}_{1} \times \mathrm{L}_{3}, \mathrm{~L}_{1} \times \mathrm{L}_{5}, \mathrm{~L}_{2} \times \mathrm{L}_{3}, \mathrm{~L}_{2} \times \mathrm{L}_{5}\right.$ and $\left.\mathrm{L}_{3} \times \mathrm{L}_{5}\right)$ showed values of heterosis ranged from $61 \%$ to $69.23 \%$ and the crosses of $\mathrm{L}_{4} \times \mathrm{L}_{5}$ and $\mathrm{L}_{3} \times \mathrm{L}_{4}$ registered heterosis values of $54 \%$ and $55.5 \%$, respectively. For 100 -seed weight, heterosis was in the range from $4.25 \%\left(\mathrm{~L}_{3} \times \mathrm{L}_{5}\right)$ to $23.2 \%\left(\mathrm{~L}_{1} \times \mathrm{L}_{4}\right)$ with an average of $10.5 \%$. Heterosis for yield $t /$ ha was in the range from $58 \%\left(\mathrm{~L}_{4} \times \mathrm{L}_{5}\right)$ to $82 \%\left(\mathrm{~L}_{2} \times \mathrm{L}_{4}\right)$ with an average of $67 \%$. One cross $\left(L_{1} \times L_{5}\right)$ gave a heterosis of $72 \%$, the remainder of the crosses showed a heterosis values ranged from $60 \%$ to $68 \%$ (Table 5).

\subsection{Degree of Cross-Fertilization}

Table 6 shows the mean, range and mean sum of squares for the degree of cross-fertilization of the five lines. There was significant $(p<0.01)$ variation among the inbred lines for the degree of cross-fertilization. Amongst their progenies a total of 692 individuals were white and 266 were black. The degree of cross-fertilization was in the range from $28.1 \%$ (Shabah) to $46.9 \%$ (Ed-Damar) with an average of $36 \%$.

Table 5. Heterosis percentage relative to mid parents for yield and yield traits in faba bean.

\begin{tabular}{ccccc}
\hline Cross/trait & $\begin{array}{c}\text { Plant height } \\
(\mathrm{cm}) \mathrm{PH}\end{array}$ & Pods/plant & $\begin{array}{c}100 \text {-seed } \\
\text { weight }(\mathrm{g})\end{array}$ & Yield t/ha \\
\hline L1 $\times$ L2 & 16.15 & 67.90 & 21.24 & 65.58 \\
L1 $\times$ L3 & 21.20 & 61.82 & 5.30 & 66.13 \\
L1 $\times$ L4 & 17.00 & 50.00 & 23.20 & 67.22 \\
L1 $\times$ L5 & 9.74 & 61.00 & 7.70 & 72.00 \\
L2 $\times$ L3 & 9.97 & 62.64 & 7.45 & 61.50 \\
L2 $\times$ L4 & 15.00 & 89.00 & 12.61 & 82.00 \\
L2 $\times$ L5 & 13.50 & 66.40 & 7.90 & 60.00 \\
L3 $\times$ L4 & 6.87 & 55.50 & 5.60 & 67.09 \\
L3 $\times$ L5 & 8.75 & 69.40 & 4.25 & 68.27 \\
L4 $\times$ L5 & 6.00 & 54.29 & 9.45 & 58.00 \\
Mean & 12.33 & 64.00 & 10.50 & 67.00 \\
\hline
\end{tabular}


Table 6. Mean, range and mean squares from the analysis of variance the degree of cross-fertilization in five faba bean lines.

\begin{tabular}{cc}
\hline Lines & Degree of cross-fertilization \\
\hline Mean & $36.0 \pm 7.8$ \\
Range & $28.1-46.9$ \\
LSD & 3.9 \\
C.V & 10.4 \\
Mean squares & $169.64^{* *}$ \\
\hline
\end{tabular}

${ }^{*}$ Significance at 0.01 .

\subsection{Synthetic Performance}

Mean squares from the analysis of variance (Table 7) showed highly significant differences ( $p \leq 0.01$ ) among the entries (lines blends in Syn-0 and Syn-1) for the studied traits. Generally, the increase in mean performance of lines blends for the studied traits in Syn-1 relative to Syn-0 was $24 \%$ for plant height, $13 \%$ for number of pods per plants and yield $(\mathrm{t} / \mathrm{ha})$; however, no significant increase in 100 -seed weight of Syn-1 compared to Syn- 0 was observed. For the performance of the lines blend, the tallest plant height was recorded by M8 in Syn-0 $(76.6 \mathrm{~cm})$ and M13 $(92.9 \mathrm{~cm})$ in Syn-1. In Syn-0, M3, M7 and M15 gave the highest number of pods per plant (25), whereas M2 and M13 registered the highest number of pods per plant (29) in Syn-1. M2 gave the highest yield of $3.4 \mathrm{t} / \mathrm{ha}$ for Syn-0 and $3.96 \mathrm{t} / \mathrm{ha}$ for Syn-1. On the other hand, the lowest yield of $2.13 \mathrm{t} / \mathrm{ha}$ and $2.39 \mathrm{t} /$ /ha was given by M11 in Syn-0and Syn-1, respectively (Table 6). The blend M2 was formed from four lines, namely Hudieba/93, Ed-Damar, Shabah, and Bassabier. The increase in performance of the four lines in Syn-1 compared to Syn- 0 was $13 \%$ for plant height and number of pods per plant and $14 \%$ for yield $t / h a$. Compared to the average yield $t / h a$ of the pure stand of the lines (3.07), the increase in yield of M2 was $11 \%$ in sy-0 and 29\% in Syn-1. Compared with individual yield $t / h a$ of the pure stand of the lines, $2.99 \mathrm{t} / \mathrm{ha}$ for Hudeiba/93 and Bassabier, 3.17 for Ed-Damar, $3.27 \mathrm{t} / \mathrm{ha}$ for Shabah and $2.96 \mathrm{t} / \mathrm{ha}$ for Selaim, (Table 1), the performance of Syn-0 in M2 surpassed the yield of pure stands of Hudeiba/93 and Bassabier by $14 \%$, Ed-Damar by $7 \%$, Shabah by $4 \%$, and Selaim by $15 \%$. For Syn-1, and as a result of increasing heterozygosity, the yield increase in M2 compared with the corresponding yield of the lines grown in pure stands was $32 \%$ of Hudeiba/93 and Bassabier, 25\% of Ed-Damar yield, and 21\% of Shabah yield and $34 \%$ of Selaim yield.

\section{Discussion}

\subsection{Variability and Mean Performance of the Entries}

To improve yield potentials of a crop, in breeding program, it is important to create new combinations of genes to produce genotype with trait performance that is superior to current genotypes at the target environment [14]. In the present study, the highly significant variations among the parental lines and their possible $F 1$-hybrids for the studied traits provide evidence for the presence 
Table 7. Mean performance of yield and yield traits in sixteen blends for five faba bean genotypes in Syn-0 and Syn-1 generation.

\begin{tabular}{|c|c|c|c|c|c|c|c|c|}
\hline \multirow[t]{2}{*}{ blend/trait } & \multicolumn{2}{|c|}{ Plant height $(\mathrm{cm})$} & \multicolumn{2}{|c|}{ pods/plant } & \multicolumn{2}{|c|}{100 -seed weight $(\mathrm{g})$} & \multicolumn{2}{|c|}{ Yield t/ha } \\
\hline & SYN-0 & Syn-1 & Syn-0 & Syn-1 & Syn-0 & Syn-1 & Syn-0 & Syn-1 \\
\hline M1 & 70.40 & 89.2 & 22 & 26 & 50.60 & 50.60 & 2.59 & 3.27 \\
\hline M2 & 72.60 & 82.10 & 24 & 29 & 52.20 & 55.20 & 3.40 & 3.96 \\
\hline M3 & 70.90 & 83.90 & 25 & 27 & 57.80 & 57.90 & 2.73 & 3.01 \\
\hline M4 & 70.80 & 82.20 & 23 & 25 & 50.00 & 50.10 & 2.64 & 2.94 \\
\hline M5 & 69.50 & 86.30 & 24 & 28 & 53.10 & 53.10 & 2.64 & 3.22 \\
\hline M6 & 69.80 & 85.30 & 24 & 26 & 51.60 & 51.70 & 2.75 & 3.04 \\
\hline M7 & 69.00 & 89.10 & 25 & 28 & 53.90 & 53.90 & 2.82 & 3.22 \\
\hline M8 & 76.60 & 88.10 & 24 & 26 & 47.20 & 47.20 & 2.82 & 2.92 \\
\hline M9 & 65.50 & 80.50 & 23 & 26 & 49.90 & 50.80 & 2.88 & 2.95 \\
\hline M10 & 70.70 & 90.50 & 24 & 26 & 55.20 & 58.50 & 2.63 & 2.84 \\
\hline M11 & 63.90 & 85.20 & 21 & 24 & 51.50 & 52.80 & 2.13 & 2.39 \\
\hline M12 & 66.60 & 91.80 & 23 & 26 & 52.90 & 53.90 & 2.42 & 3.10 \\
\hline M13 & 69.20 & 92.90 & 22 & 29 & 57.40 & 57.40 & 2.66 & 2.96 \\
\hline M14 & 69.80 & 89.90 & 23 & 27 & 55.50 & 58.90 & 2.63 & 2.91 \\
\hline M15 & 73.00 & 83.60 & 25 & 26 & 46.60 & 46.60 & 2.26 & 2.82 \\
\hline M16 & 71.50 & 88.90 & 22 & 27 & 51.30 & 54.10 & 2.35 & 2.87 \\
\hline Mean & 69.99 & 86.84 & 23.38 & 26.50 & 52.30 & 53.29 & 2.68 & 3.01 \\
\hline C.V & \multicolumn{2}{|c|}{7.31} & \multicolumn{2}{|c|}{8.41} & \multicolumn{2}{|c|}{7.48} & \multicolumn{2}{|c|}{11.54} \\
\hline $\mathrm{LSD}_{0.05}$ & \multicolumn{2}{|c|}{8.53} & \multicolumn{2}{|c|}{3.6} & \multicolumn{2}{|c|}{3.8} & \multicolumn{2}{|c|}{0.28} \\
\hline
\end{tabular}

of a wide genetic variability among the lines and $F 1$-hybrids produced from them; indicating that the genetic improvement is possible in the present genetic material. Moreover, the wide range in the mean performance for the traits: plant height, number of pods per plant, 100-seed weight and yield; among the entries accompanied with high heritability (broad-sense) of $0.71-0.95$ confirm the presence of sufficient genetic variability and possibility of selection and improvement of yield and yield traits in the present faba bean germplasm. Similar results were reported by [15] [16] [17].

\subsection{General and Specific Combining Ability, Hetesosis and Production of Synthetic Cultivar}

In any breeding program, it is very important to know the combining abilities of the inbred lines that are used as parents in hybrids [9] [18]. Combining ability helps the breeder to identify the best combiners which may be hybridized either to exploit heterosis or to build up favorable fixable genes [19] [20].

In the present investigation, the highly significant mean squares for both general combining ability (GCA) and specific combining ability may indicate the 
importance of both additive and dominance gene effect in the inheritance of the studied traits. Moreover, the higher mean squares from the analysis of variance for GCA of the traits than of SCA showed the great contribution of the additive effects of genes in the expressions of the traits. Therefore, selection will be effective for improvement of yield and yield traits in the present genetic material. Several researchers have reported on the significance of both general and specific combining ability effects on yield and yield traits in faba bean and found similar results, e.g. [20] [21].

Form the results, the highest GCA given by Hudeiba/93 line for plant height, number of pods per plant and number of seeds per pod and the highest GCA exhibited by Shabah line for 100-seed weight as well as that showed by Bassabier line for pods per plant and yield ( $\mathrm{t} / \mathrm{ha}$ ), indicate that these lines are the good combiner for the mentioned traits; therefore the improvement of such traits is rather predictive and more heterosis and high yield performance could be expected upon crossing. These findings are in agreement with those reported by [16] [21] [22]. Moreover, the positive SCA exhibited by the crossing $\mathrm{L}_{2} \times \mathrm{L}_{4}$ for plant height and pods per plant and that positive significant SCA effect given by the cross of Shabah $\times$ Selaim for 100 -seed weight as well as the desirable positive SCA exhibited by all crosses for grain yield $\mathrm{t} / \mathrm{ha}$ indicated that both additive and non-additive effects of the genes played a role in controlling faba bean yield as reported by [15] [17] [23] Therefore, as Hudeiba/93, Bassabier and Shabah lines exhibited the highest GCA and highest SCA upon crossing, they represent the presence of suitable genetic material for a breeder to build a future program to improve faba bean yield through selection and hybridization. The average amount of heterosis present in plant height (12.33\%), number of pods per plant (64\%), 100-seed weight $(10.50 \%)$ and in yield t/ha (67\%), indicate the presence of sufficient amount of heterosis, which could be used as a base for an effective breeding program for improvement of yield of the local faba bean gene in the semi-arid zone of Sudan. similar results were reported by other workers, e.g., [16] [17] [23] [24] [25].

In the present study the high degree of cross-fertilization of $36 \%$ and high heterosis (67\%) exhibited by the lines under the study as well as their highly significant positive GCA and SCA indicate the presence of the prerequisites for production of synthetic cultivars. For the number of parental lines, the high and significant performance for yield and yield traits obtained by mixture M2 (the mixture of Hudeiba/93, Bassabier, Ed-Damar and Shabah lines) in Syn-0 and Syn-1 compared to performance of each of the line, indicate that synthetic cultivars could be developed from these four lines. Moreover, the increase in overall yield performance from $3.40 \mathrm{t} / \mathrm{ha}$ in Syn-0 to 3.96 in Syn-1 indicates the effect of heterozyosity as well as the joint effect of heterogeneity and hetrozygosity in Syn-1, which is expected to increase and give high yield performance in Syn-2 and Syn-3 [3] as maximum heterosis is not achieved in Syn-1 but could be realized in later generations [8]. [8] pointed out that the maximum amount of he- 
terosis will take until Syn-4 to realize nearly maximum amount of heterosis as synthetic exploited more additive gene action compared with hybrid which exploited non additive genes [9] [26]. Moreover, and for maximum synthetic yield, it is recommended to increase the degree of cross-fertilization before commercialization as reported by [8] and [27].

\section{Conflicts of Interest}

The authors declare no conflicts of interest regarding the publication of this paper.

\section{References}

[1] Jensen, E.S., Peoples, M.B. and Hauggaard-Nielsen, H. (2010) Faba Bean in Cropping System. Field Crops Research, 115, 203-216. https://doi.org/10.1016/j.fcr.2009.10.008

[2] Abdelmula, A. and Abuanja, I. (2007) Genotypic Responses, Yield Stability and Association between Characters among Some of Sudanese Faba Bean (Vicia faba L.) Genotypes under Heat Stress. Tropping Research for Development, University of Kassel, Witzenhausen; University of Goettingen, Chöttingen, 1-7.

[3] Stelling, D., Link, W. and Ebmeyer, E. (1994) Yield Stability in faba bean (Vicia faba L.). 2. Effects of heterozygosity and heterogeneity. Plant Breeding, 112, 30-39. https://doi.org/10.1111/j.1439-0523.1994.tb01273.x

[4] Duc, G., Berthaut, N., Berthelem, P., Le Guen, J. and Picard, J. (1992) Hybrid Breeding in Faba Bean (Vicia faba L.). Proceeding of the 1 st European Conference on Grain Legumes, Angers, 1-3 June 1992, 45-46.

[5] Ebmeyer, E. (1988) Heterosis and Genetic Variances and Their Implications for Breeding Improved Varieties of Spring Beans (Vicia faba L.). Plant Breeding, 101, 200-207. https://doi.org/10.1111/j.1439-0523.1988.tb00288.x

[6] Gasim, S. and Link, W. (2007) Agronomic Performance and the Effect of Self Fertilization on German Winter Faba. Journal of Central Europ of Agriculture, 8, 121-127.

[7] Bernardo, R. (2002) Breeding for Quantitative Traits in Plants. Stemma Press, Woodbury, MN.

[8] Link, W., Stelling, D. and Ebmeyer, E. (1994) Factors Determining the Performance of Synthetics in Vicia faba L. 1. Heterogeneity, Heterozygosity and Degree of Cross-Fertilization. Euphytica, 75, 77-84. https://doi.org/10.1007/BF00024534

[9] Welu, G. (2016) Development and Application of Synthetic Varieties in Crop Improvement. International Journal of Engineering Development and Research, 4, 424-429.

[10] Adam, H.S. (1996)The agriculture climate. Dar Alassla Publication, 57.

[11] Link, W. (1990) Autofertility and Rate of Cross-Fertilization: Crucial Characters for Breeding Synthetic Varietiesin Faba Bean (Vicia faba L.). Theoretical and Applied Genetics, 79, 713-717. https://doi.org/10.1007/BF00226888

[12] Schnell, F.W. (1961) Heterosis and Inbreeding Effect. In: Schriftenreihe des MPI für Tierzucht und Tierernährung, Special Vol. 1961, Mariensee, 251-272.

[13] Griffing, B. (1956) Concept of General and Specific Combining Ability in Relation to Diallel Crosses Systems. Australain Journal of Biological Science, 9, 463-493. 
https://doi.org/10.1071/BI9560463

[14] Govindaraj, M., Vetriventhan, M. and Srinivasan, M. (2015) Importance of Genetic Diversity Assessment in Crop Plants and Its Recent Advances: An Overview of Its Analytical Perspectives. Genetics Research International, 2015, Article ID: 431487.

[15] Awaad, H.A., Salem, A.H., Mohsen, A.M., Atia, M.M., Hassan, E.E., Amer, M.I. and Moursi, A.M. (2005) Assessment of Some Genetic Parameters for Resistance to Leaf Miner, Chocolate Spot, Rust and Yield of Faba bean in F2 and F4 Generations. Egyptian Journal of Plant Breeding, 9, 1-15.

[16] Ibrahim, H.M. (2010) Heterosis, Combining Ability and Components of Genetic Variance in Faba Bean (Vicia faba L.). Environment and Arid Land Agricultural Science, 21, 35-50. https://doi.org/10.4197/met.21-1.3

[17] Zeinab, E.G. and Helal, A.G. (2014) Heterosis and Combining Ability in Diallel Cross of Eight Faba Bean Genotypes. Asian Journal of Crop Science, 1, 66-76.

[18] Khalil, A.S. and Collins, J.J. (2010) Synthetic Biology: Applications Come of Age. Nature Reviews. Genetics, 11, 367-379. https://doi.org/10.1038/nrg2775

[19] Becker, H.C. and and Léon, J. (1988) Stability Analysis in Plant Breeding. Plant Breeding, 101, 1-23. https://doi.org/10.1111/j.1439-0523.1988.tb00261.x

[20] Attia, S.M. and Morsy, S.M. (2001) Diallel Analysis of Some Yield and Technological Characters among Four Faba Bean Genotypes with Their Crosses. Annals of Agricultural Science. Moshtohor, Faculty of Agriculture Zagazig University, 39, 65-75.

[21] Attia, S.M. and Salem, M.M. (2006) Analysis of Yield and Its Components Using Diallel Mating among Five Parents of Faba Bean. Egyptian Journal of Plant Breeding, 10, 1-12.

[22] El-Hady, M.M., Olaa, S.M.A., El-Galaly, A.M. and Salem, M.M. (2006) Heterosis and Combining Ability Analysis of Some Faba Bean Genotypes. Journal of Agricultural Research, 32,134-148.

[23] Alghamdi, S.S. (2009) Heterosis and Combining Abilityin a Diallel Cross of Eight Faba Bean (Vicia faba L.) Genotypes. Asian Journal of Crop Science, 1, 66-76. https://doi.org/10.3923/ajcs.2009.66.76

[24] Zeid, M., Schön, C.C. and Link, W. (2004) Hybrid Performance and AFLP-Based Genetic Similarity in Faba Bean. Euphytica, 139, 207-216. https://doi.org/10.1007/s10681-004-3156-5

[25] Tantawy, D.M., Khaled, A.G.A. and Hosseny, M.H. (2007) Genetic Studies for Some Agronomic Characters in Faba Bean (Vicia faba L.). Assiut Journal of Agricultural Sciences, 38, 117-137.

[26] Mohammed, A.H. (2013) Breeding to Derive New Suitable Maize (Zea mays L). Variety for Spring Season. Journal of Tikrit University for Agricultural Science, 13.

[27] Wright, A.J. (1977) Inbreeding in Synthetic Varieties of Field Bean (Vicia faba L.). Journl of Agriculural Science, 89, 495-501. 